\title{
Lung Cancer Screening in Primary Care
}

Katy Rooney, MD

Ann Fam Med 2020;18(3):iii. https://doi.org/10.1370/afm.2540.

The Annals of Family Medicine encourages readers to develop a learning community to improve health care and health through enhanced primary care. Participate by conducting a journal club. We encourage diverse participants to think critically about important issues affecting primary care and act on those discussions. ${ }^{1}$

\section{HOW IT WORKS}

In each issue, the Annals selects an article and provides discussion tips and questions. Post a summary of your conversation in our online discussion. (Open the article, click on the eLetters tab, and submit a comment.) Discussion questions and information are online at: http://www.AnnFamMed.org/.

\section{CURRENT SELECTION}

\section{Article for Discussion}

Handy JR Jr, Skokan M, Rauch E, et al. Results of lung cancer screening in the community. Ann Fam Med. 2020;18(3):243-249.

\section{Discussion Tips}

The National Lung Screening Trial (NLST) is a randomized control trial that established low-dose CT as a modality for lung cancer screening in primary care. ${ }^{2}$ The study found that, compared with chest radiography, lung cancer screening with low-dose CT reduces mortality from lung cancer. ${ }^{2}$ One limitation to this study was that several of the medical institutions where the NLST was conducted are well known for their expertise in radiology and oncology. Therefore, the generalizability of the findings of the NLST study within a community setting has been questioned and the American Academy of Family Physicians (AAFP) stated that "the evidence is insufficient to recommend for or against screening for lung cancer with low-dose computed tomography." The AAFP recommends shared decision making between the physician and the patient to determine if lung cancer screening should be performed in patients who meet the criteria for screening according to the United States Preventive Services Task Force guidelines. ${ }^{3,4}$ The current study in this issue of Annals of Family Medicine by Handy et al seeks to evaluate the generalizability of lung cancer screening within a community health setting. ${ }^{5}$

\section{Discussion Questions}

- What question is asked by this study and why does it matter?

- What type of research study was conducted by the authors? How does this differ from the research study used in the NLST?

- How does this study advance beyond previous research and clinical practice on this topic?

- To what degree can the findings be accounted for by: The community health system at which the study was conducted? The health system's providers involved in the study?; Differences in baseline characteristics of the patient cohort compared with the cohort studied in the NLST? How the patients were selected, excluded, or lost to follow-up?; Lack of blinding?; Methods used to ensure study follow-up?; How the outcomes were measured?; How the findings were interpreted?

- What are the main study findings?

- How comparable is the health system to your setting? How comparable is the study sample to those in your practice? What about the transportability of the findings?

- How might this study change your practice?

- What researchable questions remain?

\section{References}

1. Stange KC, Miller WL, McLellan LA, et al. Annals Journal Club: It's time to get RADICAL. Ann Fam Med. 2006;4(3):196-197. http:// annfammed.org/cgi/content/full/4/3/196.

2. Aberle DR, Adams AM, Berg CD, et al; National Lung Screening Trial Research Team. Reduced lung-cancer mortality with low-dose computed tomographic screening. N Engl J Med. 2011;365(5): 395-409.

3. American Academy of Family Physicians. Clinical preventive service recommendation; Lung cancer. https://www.aafp.org/patient-care/ clinical-recommendations/all/lung-cancer.html. Published 2013. Accessed Mar 24, 2020.

4. US Preventive Services Task Force. Lung cancer: screening. http:// www.uspreventiveservicestaskforce.org/Page/Document/RecommendationStatementFinal/lung-cancer-screening. Published Dec 2013. Updated Sep 25, 2014. Accessed Mar 24, 2020.

5. Handy JR Jr, Skokan M, Rauch E, et al. Results of lung cancer screening in the community. Ann Fam Med. 2020;18(3):243-249. 